\title{
Effects of Emotional Labor for Aestheticians on Job Stress, Satisfaction, and Turnover
}

\author{
Sang-Sook Seo, Chul-Ho Park \\ Department of Cosmetology Science, Nambu University, Gwangju, Korea
}

\author{
*Corresponding author: Chul-Ho Park, \\ Department of Cosmetology Science, \\ Nambu University, 23 Chumdanjungang-ro, \\ Gwangsan-gu, Gwangju 62271, Korea \\ Tel.: +82 629700140 \\ Fax: +82 629700140 \\ Email: chpark@nambu.ac.kr
}

Received March 7, 2018

Revised May 31, 2018

Accepted June 29, 2018

Published September 30, 2018

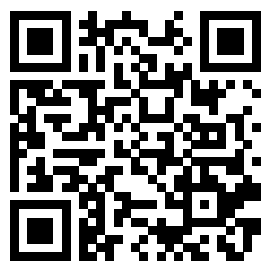

\begin{abstract}
Purpose: The purpose of this study was to seek efficient human management plan by investigating the effects of emotional labor of aestheticians on job stress, job satisfaction, and turnover intention. Methods: For the empirical analysis of this study, we used a statistical package for social science (SPSS) 18.0 statistical package program and autonomous marine operations and systems (AMOS) 18.0 program. We conducted a frequency analysis to investigate general characteristics of the research targets. We performed an exploratory factor analysis in order to verify the validity of the measurement tools and calculated Cronbach's $\alpha$ coefficient to verify the reliability of the factors. We verified the causal relation between constructs using the structural equation model in order to verify the research hypothesis. Results: As a result of the study, it was found that job stress and turnover intention increased as the surface acting of emotional labor increased, and job stress decreased and job satisfaction increased as the deep acting of emotional labor increased. Job satisfaction decreased, and turnover intention increased, as job stress increased, turnover intention decreased as job satisfaction increased. Conclusion: In order to reduce the turnover intention of estheticians, it is necessary to improve job satisfaction and reduce emotional labor. In order to reduce emotional labor, systematic education, such as self-esteem improvement training for estheticians, stress management, and active corresponding measures for bad clients are necessary, and it is necessary to improve the working environment and client-first client-facing law in order to improve job satisfaction.
\end{abstract}

Keywords: Aesthetician, Emotional labor, Job stress, Job satisfaction, Turnover intention

\section{Introduction}

경제가 발전하고 서비스 부분이 차지하는 비중이 점차 증가 함에 따라 고객만족과 접객서비스가 기업의 경쟁우위를 결정하 는 수단으로 인식되면서 인간감정의 상품화가 진행되기 시작하 였다. 특히 피부미용산업은 무형적 속성이 강하여 고객욕구를 충 족시킬 수 있는 서비스 품질의 제공과 그로 인한 고객 만족 활동 이 중요하다(Kim et al., 2011). 피부미용서비스업에서의 고객 만족은 고객과 서비스를 제공하는 피부미용사 사이의 상호작용 이 품질에 의해 영향을 받으며, 특히 인적 서비스가 이상적으로 제공되어야만 매출과 이윤을 창출할 수 있다는 점에서 피부미용 사는 매우 중요한 자원이라고 할 수 있다(Park \& Park, 2010).
그러나 피부미용산업의 성장에 따른 동종 업종간의 과도한 경쟁 은 피부미용사들이 바람직한 감정표현을 하고 부적절한 감정표 현을 나타내지 못하도록 강요되었고 이에 따른 높은 이직률은 경 영성과를 달성하는데 부정적인 영향을 미치게 되었다(Park et al., 2013). 이처럼 피부미용산업은 인력에 대한 의존도가 큰 업 종이기에 인력에 대한 효율적인 연구와 관리가 필요하다(Lee et al., 2012). 그러나 인적 관리의 개선이 체계적으로 정립되어 있 지 못할 뿐만 아니라 인적자원관리가 실현되고 있는가에 대한 인 식조차 전무한 실정이다(Cha \& Youn, 2015).

Hochschild (1979)는 서비스 노동에 종사하는 사람들은 육체 노동 이외에도 그것들과 차별화될 수 있는 또 하나의 노동을 수 행하고 있음에 주목하고 이러한 특유한 현상을 감정노동이라 명 
명하였다. Hochschild (1983)는 종사자의 감정표현을 표면행위 (surface acting)와 내면행위(deep acting)로 구분하여 제시하 였다. 겉으로 드러나는 행위만을 포장하여 보여주는 표면화 행위 는 자기 스스로를 속이지는 못하는 반면, 내면 행위는 작위적인 노력을 통해 표현하고자 하는 감정을 불러일으키거나 억누르는 시도, 관련된 감정을 유도하기 위해 생각, 이미지, 기억 등을 떠 올리는 노력을 통해 수행되는데 이러한 노력들을 통하여 진심으 로 원하는 감정을 형성하려고 몰입하는 것을 의미한다(Chae \& Bae, 2014).

감정노동 관련 미용분야 선행연구를 보면 미용서비스 종사자 의 감정노동(Kang \& Rhee, 2012; Lee, 2017; Park et al., 2013; Sin \& Chung, 2017), 헤어 미용업 종사자의 감정노 동(Chun \& Jin, 2015; Jung \& Shim, 2012; Oh \& Song, $2015)$, 화장품 판매원의 감정노동 $(\mathrm{Im}, 2014 ; \mathrm{Im}, 2016$; Im, 2017; Cho \& Chang, 2015), 네일 살롱 종사자의 감정노동(Lee et al., 2016)을 스트레스, 직무소진, 직무만족, 이직의도와 연 관시켜 분석한 연구가 있다. 피부미용사의 감정노동과 소진에 대 해 연구한 $\operatorname{Kim}$ (2012)은 감정노동이 증가할수록 소진이 증가한 다고 발표하였고, 감정노동과 직무스트레스에 대해 연구한 $\mathrm{Kim}$
(2014)과 Yoo et al. (2012)은 감정노동이 증가할수록 직무스트 레스가 증가한다고 발표하였다. Shin \& Mo (2017)는 감정노동 이 직무소진, 직무만족에 영향을 미치는데 사회적 지원이 중요하 다고 발표하였다.

이처럼 선행연구들이 일반적인 미용종사자의 감정노동을 다루 기 때문에 피부미용사의 특성을 반영하지 못하고 있고, 피부미용 사의 감정노동이 영향을 미치는 요인으로 직무소진, 직무만족, 직무스트레스 중 하나 또는 두 가지 요인의 영향으로 설명하고 있다. 본 연구에는 피부미용사의 감정노동이 직무스트레스, 직무 만족, 이직의도에 미치는 영향을 알아봄으로써 효율적인 인적 관 리 방안을 위한 기초자료로 활용하고자 한다.

\section{Methods}

\section{1. 연구가설}

본 연구는 피부미용사의 감정노동에 대한 실증적 연구를 통하 여 피부미용사의 감정노동이 직무스트레스, 직무만족, 이직의도 에 영향을 미친다는 가설을 설정하였다.

\section{Table 1. Demographic characteristics of the sample}

\begin{tabular}{|c|c|c|c|}
\hline Division & & Frequency $(\mathrm{N})$ & Percent (\%) \\
\hline \multirow{5}{*}{ Age } & Under 20 & 33 & 9.2 \\
\hline & $21-30$ & 77 & 21.5 \\
\hline & $31-40$ & 87 & 24.3 \\
\hline & $41-50$ & 120 & 33.5 \\
\hline & Over 51 & 41 & 11.5 \\
\hline \multirow{3}{*}{ Marital status } & Single & 145 & 40.5 \\
\hline & Married & 205 & 57.3 \\
\hline & Others & 8 & 2.2 \\
\hline \multirow{4}{*}{ Educational background } & High school graduate & 114 & 31.8 \\
\hline & College (in school) graduate & 106 & 29.6 \\
\hline & University (in school) graduate & 104 & 29.1 \\
\hline & Postgraduate school (in school) graduate & 34 & 9.5 \\
\hline \multirow{3}{*}{ Position } & Controller & 119 & 33.2 \\
\hline & General manager & 59 & 16.5 \\
\hline & Director & 180 & 50.3 \\
\hline \multirow{5}{*}{ Aesthetic career } & Under 1 year & 61 & 17.0 \\
\hline & $1-3$ years & 62 & 17.3 \\
\hline & 3-6 years & 64 & 17.9 \\
\hline & $6-9$ years & 47 & 13.1 \\
\hline & Over 10 years & 124 & 34.6 \\
\hline \multirow{5}{*}{ Average monthly income } & Under $1,000,000$ won & 43 & 12.0 \\
\hline & Under $100-1,500,000$ won & 45 & 12.6 \\
\hline & Under $150-2,000,000$ won & 66 & 18.4 \\
\hline & Under $200-2,500,000$ won & 55 & 15.4 \\
\hline & Over $2,500,000$ won & 149 & 41.6 \\
\hline \multirow{2}{*}{ Working hours } & Under $8 \mathrm{~h}$ & 90 & 25.1 \\
\hline & Over $8 \mathrm{~h}$ & 268 & 74.9 \\
\hline Total & & 358 & 100.0 \\
\hline
\end{tabular}


$\mathrm{H} 1$ 피부미용 종사자의 감정노동은 직무스트레스에 유의미한 영 향을 미칠 것이다.

H1-1 피부미용 종사자의 표면행위는 직무스트레스에 유의미한 정 $(+)$ 의 영향을 미칠 것이다.

H1-2 피부미용 종사자의 내면행위는 직무스트레스에 유의미한 부(-)의 영향을 미칠 것이다.

$\mathrm{H} 2$ 피부미용 종사자의 감정노동은 직무만족에 유의미한 영향을
미칠 것이다.

H2-1 피부미용 종사자의 표면행위는 직무만족에 유의미한 부 $(-)$ 의 영향을 미칠 것이다.

H2-2 피부미용 종사자의 내면행위는 직무만족에 유의미한 정 (+)의 영향을 미칠 것이다.

$\mathrm{H} 3$ 피부미용 종사자의 감정노동은 이직의도에 유의미한 영향을 미칠 것이다.

Table 2. Reliability of measurement tools

\begin{tabular}{llcc}
\hline Division & & Question number & Cronbach's $\alpha$ \\
Emotional labor & Surface acting & 5 & 0.768 \\
Job stress & Deep acting & 5 & 0.884 \\
Job satisfaction & & 6 & 0.920 \\
Turnover intention & & 6 & 0.908 \\
\hline
\end{tabular}

Table 3. Exploratory factor analysis of emotional labor

\begin{tabular}{|c|c|c|c|}
\hline \multirow{2}{*}{ Division } & & \multicolumn{2}{|c|}{ Components } \\
\hline & & Factor 1 & Factor 2 \\
\hline \multirow{5}{*}{ Factor 1 deep acting } & 9. Most of the emotions I express to my clients come from my heart. & 0.870 & -0.057 \\
\hline & 7. I try to get the feelings I need to express to the clients from the whole (true) heart. & 0.857 & 0.046 \\
\hline & $\begin{array}{l}\text { 10. I responded kindly to the clients, not from the discipline of the workplace but from } \\
\text { the actual feelings. }\end{array}$ & 0.841 & -0.069 \\
\hline & 8. I try to treat my clients sincerely and kindly to project a good image. & 0.800 & 0.126 \\
\hline & $\begin{array}{l}\text { 6. I want to feel the feelings that I have to show to my clients not only outwardly but } \\
\text { deeply. }\end{array}$ & 0.761 & 0.012 \\
\hline \multirow{5}{*}{$\begin{array}{l}\text { Factor } 2 \text { surface } \\
\text { acting }\end{array}$} & 4. I serve clients in a kindly manner. & -0.031 & 0.843 \\
\hline & 5. I think of the point of contact with clients as a "stage for job performance". & 0.094 & 0.806 \\
\hline & 3. I often hide my frank feelings when I deal with clients. & -0.074 & 0.711 \\
\hline & 1. I provide service to the end without expressing disgust to rude clients. & 0.243 & 0.608 \\
\hline & $\begin{array}{l}\text { 2. I feel confused because of uncomfortable feelings when I serve clients with } \\
\text { emotions that I feel and other emotions. }\end{array}$ & -0.107 & 0.606 \\
\hline \multicolumn{2}{|l|}{ Unique value } & 3.502 & 2.629 \\
\hline \multicolumn{2}{|c|}{ Variance explanation (\%) } & 35.024 & 26.286 \\
\hline \multicolumn{2}{|c|}{ Accumulated explanation (\%) } & 35.024 & 61.310 \\
\hline
\end{tabular}

$\mathrm{KMO}=0.784$; Bartlett's test $\mathrm{X}^{2}=1627.507(\mathrm{df}=45, p=0.000)$.

KMO, Keiser-Meyer-Olkin; $\chi^{2}$, chi-square test; $\mathrm{df}$, degrees of freedom; $p, p$-value.

Table 4. Exploratory factor analysis of job stress

\begin{tabular}{|c|c|c|}
\hline & \multirow{2}{*}{ Division } & Component \\
\hline & & Factor 1 \\
\hline \multirow{6}{*}{ Factor 1 job stress } & 3. I often lose my motivation to work with the stress I receive from my clients. & 0.886 \\
\hline & 2. My pride is hurt because of the stress I receive from the clients. & 0.875 \\
\hline & 4. I feel a lot of tension in my work due to the stress I receive from my clients. & 0.858 \\
\hline & 6. I used to think that I'm unlikely to be able to serve clients due to the stress I receive from clients. & 0.828 \\
\hline & 5. I'm not enthusiastic and confident in everything due to the stress I receive from clients. & 0.825 \\
\hline & 1. I'm very stressed about emotional problems with clients. & 0.796 \\
\hline \multicolumn{2}{|l|}{ Unique value } & 4.288 \\
\hline \multicolumn{2}{|c|}{ Variance explanation (\%) } & 71.461 \\
\hline \multicolumn{2}{|c|}{ Accumulated explanation (\%) } & 71.461 \\
\hline
\end{tabular}

$\mathrm{KMO}=0.880$; Bartlett's test $\mathrm{X}^{2}=1563.295(\mathrm{df}=15, p=0.000)$.

$\mathrm{KMO}$, Keiser-Meyer-Olkin; $\chi^{2}$, chi-square test; $\mathrm{df}$, degrees of freedom; $p, p$-value. 
H3-1 피부미용 종사자의 표면행위는 이직의도에 유의미한 정 (+)의 영향을 미칠 것이다.

H3-2 피부미용 피부미용 종사자의 내면행위는 이직의도에 유 의미한 부(-)의 영향을 미칠 것이다.

$\mathrm{H} 4$ 피부미용 종사자의 직무스트레스는 직무만족에 유의미한 부(-)의 영향을 미칠 것이다.

$\mathrm{H} 5$ 피부미용 종사자의 직무스트레스는 이직의도에 유의미한 정(+)의 영향을 미칠 것이다.

$\mathrm{H} 6$ 피부미용 종사자의 직무만족은 이직의도에 유의미한 부(-) 의 영향을 미칠 것이다.

\section{2. 연구대상}

본 연구의 실증분석을 위해 서울특별시, 경기도에 거주하는 피 부미용사를 대상으로 2017년 8월부터 2017년 10월까지 총 400 부의 설문지를 배포하여 387 부를 회수하였고, 그 중 누락된 설문 을 제외한 358 부를 실증분석에 사용하였다.

\section{3. 연구내용 및 방법}

1) 설문지 구성

본 연구의 측정도구로 사용된 설문지는 총 35 문항으로 구성되 었으며. 연구에 사용된 모든 Likert척도는 5 점 척도(매우 그렇다 $=5$ 점; 전혀 아니다 $=1)$ 를 사용하였다.

인구통계학적 요인은 7 문항으로 구성되었으며 명목척도를 사 용하였다. 감정노동은 10 문항으로 감정노동을 표면행위와 내면 행위로 구분한 선행연구(Brotheridge, 2002; Grandey, 2000; Goodwin et al., 2011)를 수정, 보완하여 표면행위 5문항과 내 면행위 5 문항으로 구성하였다. 직무스트레스와 직무만족은 각 각 6문항으로 선행연구(Bae et al., 2015; Sin \& Chung, 2017) 를 수정, 보완하여 구성하였다. 이직의도는 6 문항으로 선행연구 (Chae \& Bae, 2014)를 수정, 보완하여 구성하였다.
2) 자료분석

수집된 자료는 데이터 코딩(data coding)과 데이터 크리닝 (data cleaning) 과정을 거쳐 SPSS Win 18.0 (IBM, USA) 통 계 패키지 프로그램과 $\mathrm{AMOS} 18.0$ (IBM)을 활용하여 분석하 였다. 조사대상자의 일반적 특성을 알아보기 위하여 빈도분석 (frequency analysis)을 실시하였다. 측정도구의 타당성 검증을 위해 탐색적 요인분석을 실시하였고, 요인들의 신뢰도 검증을 위 해 Cronbach's $\alpha$ 계수를 산출하였다. 연구가설을 검증하기 위해 구조방정식 모형을 활용하여 구성 개념들 간 인과관계를 검증하였 다.

\section{Results and Discussion}

\section{1. 인구통계학적 특성}

조사대상자의 인구통계학적 특성은 Table 1 과 같다. 빈도 분석 한 결과, 연령은 41-50세가 $33.5 \%$ 로 가장 높게 나타났으며, 결 혼은 기혼자가 $57.3 \%$ 로 나타났다. 학력은 고졸 $31.8 \%$, 전문대졸 이상이 $68.2 \%$ 로 나타났으며, 직위는 원장 $50.3 \%$, 관리사 $33.2 \%$ 순으로 나타났다. 피부미용 경력은 10 년 이상이 $34.6 \%$ 로 가장 높 게 나타났으며, 월평균소득은 250만원 이상 $41.6 \%, 150-200$ 만 원 미만 $18.4 \%$ 순으로 나타났다. 근로시간은 $74.9 \%$ 가 $8 \mathrm{~h}$ 이상 근무하는 것으로 나타났다.

\section{2. 측정변수에 대한 신뢰도 및 타당성 검증}

1) 신뢰도 검증

연구 요인별 Cronbach's $\alpha$ 를 살펴보면 감정노동은 하위 요인 별 표현행동이 0.768 , 내면 행위가 0.884 로 나타났고, 직무스트 레스는 0.920 , 직무만족은 0.908 , 이직의도는 0.921로 각 요인 별 신뢰도가 0.70 이상으로 나타나 신뢰할만한 수준으로 나타났다 (Table 2).

Table 5. Exploratory factor analysis of job satisfaction

\begin{tabular}{llr}
\hline Division & & Component \\
\cline { 2 - 3 } & 2. I'm satisfied with my current job. & Factor 1 \\
& 3. I feel a sense of accomplishment for the current skin care business. & 0.877 \\
Factor 1 job satisfaction & 4. I think I can demonstrate my ability in my work. & 0.876 \\
& 5. I think I rightly chose the skin beauty job. & 0.834 \\
& 6. I think that the place where I'm working at now gives me many opportunities for development. & 0.822 \\
& 1. I'm satisfied with my current work environment. & 0.797 \\
Unique value & & 0.771 \\
Variance explanation (\%) & & 6.138 \\
Accumulated explanation (\%) & 68.964 \\
\hline
\end{tabular}

$\mathrm{KMO}=0.861$; Bartlett's test $\chi^{2}=1423.217(\mathrm{df}=15, p=0.000)$.

KMO, Keiser-Meyer-Olkin; $x^{2}$, chi-square test; $\mathrm{df}$, degrees of freedom; $p, p$-value. 


\section{2) 탐색적 요인분석}

본 연구에서는 구성개념의 타당도를 검증하기 위한 탐색적 요 인분석(exploratory factor analysis)을 실시하였으며, 요인 추출 방법은 주성분분석(principal components analysis) 방식을 이 용하였고, 직각회전인 베리맥스(varimax) 방식을 사용하였다. 요 인의 수 결정은 고유값(eigen value)이 1 이상인 요인만을 선택하 였으며, 각 변수와 요인간의 상관관계를 나타내주는 요인 적재치 (factor loading)는 그 값이 0.4 이상인 경우를 유의미한 것으로 판단하였다(Oh \& Song, 2015).

(1) 감정노동에 대한 탐색적 요인분석

감정노동에 대해 탐색적 요인분석을 실시한 결과는 Table 3 와 같다. 먼저 Bartlett의 단위행렬을 점검한 결과, $\chi^{2}=1627.507$ $(p=0.000)$ 이므로 변수들 사이에 요인을 이룰만한 상관관계가 충 분하고, Keiser-Meyer-Olkin (KMO)의 표본적합도 점검결과, $\mathrm{KMO}$ 값이 0.784 로 나타났다. 누적설명력은 $61.310 \%$ 로 나타났 다.

\section{(2) 직무스트레스에 대한 탐색적 요인분석}

직무스트레스에 대해 탐색적 요인분석을 실시한 결과는 Table 4 와 같다. 먼저 Bartlett의 단위행렬을 점검한 결과, $\chi^{2}=1563.295$ $(p=0.000)$ 이므로 변수들 사이에 요인을 이룰만한 상관관계가 충 분하고, $\mathrm{KMO}$ 의 표본적합도 점검결과, $\mathrm{KMO}$ 값이 0.880 으로 나 타났다. 분산설명력은 $71.461 \%$ 로 나타났다.

\section{(3) 직무만족에 대한 탐색적 요인분석}

직무만족에 대해 탐색적 요인분석을 실시한 결과는 Table 5와 같다. 먼저 Bartlett의 단위행렬을 점검한 결과, $\chi^{2}=1423.217$ $(p=0.000)$ 이므로 변수들 사이에 요인을 이룰만한 상관관계가 충 분하고, $\mathrm{KMO}$ 의 표본적합도 점검결과, $\mathrm{KMO}$ 값이 0.861로 나타 났다. 분산설명력은 $68.964 \%$ 로 나타났다.
(4) 이직의도에 대한 탐색적 요인분석

이직의도에 대해 탐색적 요인분석을 실시한 결과는 Table 6 와 같다. 먼저 Bartlett의 단위행렬을 점검한 결과, $\chi^{2}=1545.927$ $(p=0.000)$ 이므로 변수들 사이에 요인을 이룰만한 상관관계가 충 분하고, $\mathrm{KMO}$ 의 표본적합도 점검결과, $\mathrm{KMO}$ 값이 0.894으로 나 타났다. 분산설명력은 $71.905 \%$ 로 나타났다.

3) 확인적 요인분석 결과

측정모형에 대해 확인적 요인분석(confirmatory factor analysis, CFA)을 실시한 결과는 Table 7과 같다. 분석결과 연구 단위의 적합도 지수 중 $\chi^{2}=644.943$, standardized root mean squared residual $(\mathrm{SRMR})=0.075$, goodness - of - fit index $(\mathrm{GFI})=0.887$, adjusted goodness - of - fit index $(\mathrm{AGFI})=0.858$, normed fit index $(\mathrm{NFI})=0.909$, comparative fit index $(\mathrm{CFI})=0.952$, root mean square error of approximation $(\mathrm{RMSEA})=0.053$ 으로 연구단위 적합도의 척도가 적절하게 구성 되었다는 것이 증명되었다. 또한 척도들이 해당 요인들에 대한 대 표성을 갖는지를 평가하기 위해 개념신뢰도(construct reliability, $\mathrm{CR}$ )와 평균 분산추출지수(average variance extracted, $\mathrm{AVE}$ )를 계산한 결과, 모든 요인의 $\mathrm{CR}$ 은 기준치인 0.70 보다 높게 나타났 으며, AVE도 기준치인 0.50 보다 높아 사용된 측정항목들이 충분 히 대표성을 가진다고 말할 수 있다.

\section{4) 판별타당성 검증}

구성개념간 판별타당성을 검증하기 위해 각 구성요인들 간의 상관관계를 분석한 결과는 Table 8 과 같다. 평균 분산추출(AVE) 값이 상관계수의 제곱 값보다 크면 판별타당성이 확보되었다고 할 수 있는데(Fornell \& Larker, 1981), 각 평균 분산추출(AVE) 값이 요인들 간의 상관계수의 제곱 값 $\left(\mathrm{r}^{2}\right)$ 보다 크게 나타나 각 구 성요인에 대한 판별타당성이 확보되었다고 할 수 있다.

\section{Table 6. Exploratory factor analysis of turnover intention}

\begin{tabular}{|c|c|c|}
\hline \multirow{2}{*}{ Division } & & Component \\
\hline & & Factor 1 \\
\hline \multirow{6}{*}{ Factor 1 turnover intention } & 4. I'm looking for a job opportunity to move to another job in the same field. & 0.896 \\
\hline & 5. I will accept it if I am invited to change jobs in the same field. & 0.887 \\
\hline & 2. I have a desire to move my workstation to another job in the same field. & 0.866 \\
\hline & $\begin{array}{l}\text { 6. I'm going to quit my current skin care room (I'm going to quit my current job in the last one } \\
\text { month.). }\end{array}$ & 0.827 \\
\hline & 3. I want to learn more information about employment in another field. & 0.824 \\
\hline & 1. I used to think of quitting my current skin care room. & 0.781 \\
\hline \multicolumn{2}{|l|}{ Unique value } & 4.314 \\
\hline \multicolumn{2}{|l|}{ Variance explanation (\%) } & 71.905 \\
\hline \multicolumn{2}{|l|}{ Accumulated explanation (\%) } & 71.905 \\
\hline
\end{tabular}

$\mathrm{KMO}=0.894$; Bartlett's test $X^{2}=1545.927(\mathrm{df}=15, p=0.000)$.

$\mathrm{KMO}$, Keiser-Meyer-Olkin; $\chi^{2}$, chi-square test; $\mathrm{df}$, degrees of freedom; $p, p$-value. 


\section{Table 7. Confirmatory factor analysis of the measurement model}

\begin{tabular}{|c|c|c|c|c|c|c|c|}
\hline Factor & Measurement question & $\begin{array}{c}\text { Non- } \\
\text { standard }\end{array}$ & Standard & S.E. & $t$-value & $\mathrm{CR}$ & AVE \\
\hline \multirow{5}{*}{ Surface acting } & $\begin{array}{l}\text { I provide service to the end without expressing disgust to } \\
\text { rude clients. }\end{array}$ & 1.000 & 0.504 & & & \multirow{5}{*}{0.839} & \multirow{5}{*}{0.521} \\
\hline & $\begin{array}{l}\text { I feel confused because of uncomfortable feelings when I } \\
\text { serve clients with emotions that I feel and other emotions. }\end{array}$ & 0.964 & 0.498 & 0.139 & $6.958^{* * *}$ & & \\
\hline & I often hide my frank feelings when I deal with clients. & 1.134 & 0.581 & 0.148 & $7.654^{* * *}$ & & \\
\hline & I serve clients in a kindly manner. & 1.782 & 0.824 & 0.200 & $8.917^{* * *}$ & & \\
\hline & $\begin{array}{l}\text { I think of the point of contact with clients as } \\
\text { a "stage for job performance". }\end{array}$ & 1.606 & 0.771 & 0.183 & $8.776^{\star * *}$ & & \\
\hline \multirow{5}{*}{ Deep acting } & $\begin{array}{l}\text { I want to feel the feelings that I have to show to my clients } \\
\text { not only outwardly but deeply. }\end{array}$ & 1.000 & 0.703 & & & \multirow{5}{*}{0.908} & \multirow{5}{*}{0.666} \\
\hline & $\begin{array}{l}\text { I try to get the feelings I need to express to the clients } \\
\text { from the whole (true) heart. }\end{array}$ & 1.072 & 0.881 & 0.073 & $14.743^{* * *}$ & & \\
\hline & $\begin{array}{l}\text { I try to treat my clients sincerely and kindly to project a } \\
\text { good image. }\end{array}$ & 0.985 & 0.798 & 0.072 & $13.731^{* * *}$ & & \\
\hline & $\begin{array}{l}\text { Most of the emotions I express to my clients come from } \\
\text { my heart. }\end{array}$ & 1.015 & 0.731 & 0.080 & $12.675^{* * *}$ & & \\
\hline & $\begin{array}{l}\text { I responded kindly to the clients, not from the discipline of } \\
\text { the workplace but from the actual feelings. }\end{array}$ & 0.946 & 0.678 & 0.080 & $11.828^{* * *}$ & & \\
\hline \multirow{6}{*}{ Job stress } & I'm very stressed about emotional problems with clients. & 1.000 & 0.723 & & & \multirow{6}{*}{0.913} & \multirow{6}{*}{0.636} \\
\hline & $\begin{array}{l}\text { My pride is hurt because of the stress I receive from the } \\
\text { clients. }\end{array}$ & 1.187 & 0.846 & 0.061 & $19.299^{* * *}$ & & \\
\hline & $\begin{array}{l}\text { I often lose my motivation to work with the stress I receive } \\
\text { from my clients. }\end{array}$ & 1.255 & 0.892 & 0.077 & $16.192^{* * *}$ & & \\
\hline & $\begin{array}{l}\text { I feel a lot of tension in my work due to the stress I receive } \\
\text { from my clients. }\end{array}$ & 1.195 & 0.823 & 0.079 & $15.079^{* * *}$ & & \\
\hline & $\begin{array}{l}\text { I'm not enthusiastic and confident in everything due to the } \\
\text { stress I receive from clients. }\end{array}$ & 1.070 & 0.743 & 0.079 & $13.542^{* * *}$ & & \\
\hline & $\begin{array}{l}\text { I used to think that I'm unlikely to be able to serve clients } \\
\text { due to the stress I receive from clients. }\end{array}$ & 1.129 & 0.748 & 0.083 & $13.631^{* * *}$ & & \\
\hline \multirow{6}{*}{ Job satisfaction } & I'm satisfied with my current work environment. & 1.000 & 0.646 & & & \multirow{6}{*}{0.941} & \multirow{6}{*}{0.730} \\
\hline & I'm satisfied with my current job. & 1.201 & 0.810 & 0.070 & $17.208^{* * *}$ & & \\
\hline & $\begin{array}{l}\text { I feel a sense of accomplishment for the current skin care } \\
\text { business. }\end{array}$ & 1.357 & 0.906 & 0.097 & $13.957^{* * *}$ & & \\
\hline & I think I can demonstrate my ability in my work. & 1.148 & 0.797 & 0.089 & $12.968^{* * *}$ & & \\
\hline & I think I rightly chose the skin beauty job. & 1.222 & 0.809 & 0.098 & $12.516^{* * *}$ & & \\
\hline & $\begin{array}{l}\text { I think that the place where I'm working at now gives me } \\
\text { many opportunities for development. }\end{array}$ & 1.221 & 0.759 & 0.092 & $13.258^{* * *}$ & & \\
\hline \multirow{5}{*}{ Turnover intention } & I used to think of quitting my current skin care room. & 1.000 & 0.669 & & & \multirow{5}{*}{0.909} & \multirow{5}{*}{0.627} \\
\hline & $\begin{array}{l}\text { I have a desire to move my workstation to another job in } \\
\text { the same field. }\end{array}$ & 1.164 & 0.824 & 0.074 & $15.759^{* * *}$ & & \\
\hline & $\begin{array}{l}\text { I want to learn more information about employment in } \\
\text { another field. }\end{array}$ & 1.071 & 0.753 & 0.075 & $14.314^{* * *}$ & & \\
\hline & $\begin{array}{l}\text { I'm looking for a job opportunity to move to another job in } \\
\text { the same field. }\end{array}$ & 1.252 & 0.904 & 0.084 & $14.881^{* * *}$ & & \\
\hline & $\begin{array}{l}\text { I will accept it if I am invited to change jobs in the same } \\
\text { field. }\end{array}$ & 1.292 & 0.876 & 0.089 & $14.514^{* * *}$ & & \\
\hline
\end{tabular}


$\begin{array}{lllll}\text { Turnover intention } & \text { I'm going to quit my current skin care room (I'm going to } \\ \text { quit my current job in the last one month.). } & 1.170 & 0.829 & 0.084 & 13.882^{* * *}\end{array}$

Fit statistics: $\mathrm{CMIN}=644.943, p=0.000, \mathrm{CMIN} / \mathrm{DF}=1.991, \mathrm{SRMR}=0.075, \mathrm{GFI}=0.887, \mathrm{AGFI}=0.858, \mathrm{NFI}=0.909, \mathrm{CFI}=0.952, \mathrm{RMSEA}=0.053$

${ }^{* * *} p<0.001$; S.E., standard error; CR, construct reliability; AVE, average variance extracted; CMIN ( $\left.\mathrm{X}^{2}\right)$, chi-square test; $p$, $p$-value; DF, degrees of freedom; SRMR, standardized root mean squared residual; GFI, goodness-of-fit index; AGFI, adjusted goodness-of-fit index; NFI, normed fit index; CFI, comparative fit index; RMSEA, root mean square error of approximation.

\section{3. 가설의 검증}

피부미용사의 감정노동과 직무스트레스, 직무만족, 이직의도의 관계를 검증하기 위하여 구조방정식 경로 결과 분석을 Table 9 에 나타내었다.

분석결과 $\mathrm{H} 1-1$. 감정노동 표면행위는 직무스트레스에 유의 미한 정 $(+)$ 의 영향을 미치는 변인으로 나타났다(표준화 경로계수 $0.391, p<0.001)$. 이는 피부미용 종사자 고객 응대 시 자신의 감 정을 속이고 긍정적인 것처럼 가장하는 행위가 스트레스를 증가 시킴을 의미하며, 이 결과는 감정노동이 직무스트레스를 증가시 키고 만족도를 떨어뜨린다는 Pugliesi (1999), 미용서비스 종사자 들(화장품판매원, 피부미용사)의 감정노동 중 표면행위가 많을수 록 직무스트레스가 높아진다는 $\operatorname{Im}$ (2016), Kim (2014), Sin \& Chung (2017)의 연구결과와 일치한다.
H1-2. 감정노동 내면행위는 직무스트레스에 유의미한 부(-) 의 영향을 미치는 변인으로 나타났다(표준화 경로계수 -0.249 , $p<0.001)$. 이는 피부미용 종사자가 고객 응대 시 자신의 감정을 스스로 조절하려는 노력과 고객에게 보여지는 긍정적 행위를 일치 시킴으로써 스트레스가 감소함을 의미한다. 이 결과는 고객서비 스에서 조직의 목표와 감정조절을 일치시킴으로써 부정적 감정이 낮아진다는 Totterdell \& Holman (2003)과 내면행위는 표면행위 와 반대의 결과를 가져온다는 Bae et al. (2015)의 연구결과와 일 치한다. 또한 감정노동 내면행위가 스트레스를 감소시키지만 그 영향력은 미미하다는 Sin \& Chung (2017)의 연구결과와 유사하 다.

H2-1. 감정노동 표면행위는 직무만족에 유의미한 부(-)의 영 향을 미치는 변인이라는 가설은 통계적으로 유의하지 않는 것으로

Table 8. Validation of discriminant validity between configuration concepts

\begin{tabular}{|c|c|c|c|c|c|}
\hline Division & Surface acting & Deep acting & Job stress & Job satisfaction & Turnover intention \\
\hline Surface acting & $0.521^{1)}$ & & & & \\
\hline Deep acting & $\begin{array}{c}0.045 \\
(0.002)^{2)}\end{array}$ & $0.666^{1)}$ & & & \\
\hline Job stress & $\begin{array}{l}0.368^{* * *} \\
(0.135)\end{array}$ & $\begin{array}{l}-0.215^{* * *} \\
(0.046)\end{array}$ & $0.636^{1)}$ & & \\
\hline Job satisfaction & $\begin{array}{c}0.014 \\
(0.000)\end{array}$ & $\begin{array}{l}0.502^{* * *} \\
(0.252)\end{array}$ & $\begin{array}{l}-0.337^{* * *} \\
(0.114)\end{array}$ & $0.730^{1)}$ & \\
\hline Turnover intention & $\begin{array}{l}0.218^{* * *} \\
(0.048)\end{array}$ & $\begin{array}{l}-0.283^{* * *} \\
(0.080)\end{array}$ & $\begin{array}{l}0.440^{* * *} \\
(0.194)\end{array}$ & $\begin{array}{l}-0.399^{* * *} \\
(0.159)\end{array}$ & $0.627^{1)}$ \\
\hline
\end{tabular}

${ }^{1)} \mathrm{AVE}$, average variance extracted.

${ }^{2)}$ Coefficient of determination value (squared value of correlation coefficient).

${ }^{* * *} p<0.001$.

Table 9. Analysis of path analysis of research hypotheses

\begin{tabular}{lllllllll}
\hline Hypothesis & Independent variable & Subordination variable & $\begin{array}{c}\text { Non- } \\
\text { standard }\end{array}$ & Standard & S.E. & C.R. & $p$ & Adoption status \\
H1-1 & Surface acting $\rightarrow$ & Job stress & 0.563 & 0.391 & 0.102 & $5.502^{* * *}$ & 0.000 & Adoption \\
H1-2 & Deep acting $\rightarrow$ & Job stress & -0.284 & -0.249 & 0.066 & $-4.317^{* * *}$ & 0.000 & Adoption \\
H2-1 & Surface acting $\rightarrow$ & Job satisfaction & 0.064 & 0.061 & 0.060 & 1.067 & 0.286 & Dismissal \\
H2-2 & Deep acting & Job satisfaction & 0.413 & 0.496 & 0.056 & $7.420^{* * *}$ & 0.000 & Adoption \\
H3-1 & Surface acting $\rightarrow$ & Turnover intention & 0.205 & 0.124 & 0.098 & $2.088^{*}$ & 0.037 & Adoption \\
H3-2 & Deep acting $\rightarrow$ & Turnover intention & -0.128 & -0.098 & 0.082 & -1.559 & 0.119 & Dismissal \\
H4 & Job stress $\rightarrow$ & Job satisfaction & -0.171 & -0.235 & 0.043 & $-3.982^{* * *}$ & 0.000 & Adoption \\
H5 & Job stress $\rightarrow$ & Turnover intention & 0.364 & 0.318 & 0.072 & $5.043^{* * *}$ & 0.000 & Adoption \\
H6 & Job satisfaction $\rightarrow$ & Turnover intention & -0.396 & -0.253 & 0.103 & $-3.836^{* * *}$ & 0.000 & Adoption \\
\hline
\end{tabular}

Fit statistics: $x^{2}=707.932$, SRMR $=0.076, \mathrm{GFI}=0.876, \mathrm{AGFI}=0.847, \mathrm{NFI}=0.900, \mathrm{CFI}=0.944, \mathrm{RMSEA}=0.057$

${ }^{*} p<0.05 ;{ }^{* * *} p<0.001$; S.E., standard error; CR, construct reliability; $p, p$-value; $X^{2}$, chi-square test; SRMR, standardized root mean squared residual; GFI, goodness-of-fit index; AGFI, adjusted goodness-of-fit index; NFI, normed fit index; CFI, comparative fit index; RMSEA, root mean square error of approximation. 
나타났다. 이는 피부미용 종사자의 내면행위는 직무만족에 영향을 주지만 표면행위는 직무만족에 직접적인 영향을 주지 못한다는 것 을 의미한다. 이 결과는 내면행위는 직무만족에 중요한 하나의 변 수로 작용하지만, 표면행위는 직무만족에 있어서 업무환경(동료, 업무, 근무시간 후생복지, 승진제도 등), 업무에 관한 성취감 등 다 양한 변수 중 하나임을 의미한다. 이러한 결과는 감정노동이 불가 피한 피부미용사의 경우 교육을 통하여 성취감을 향상시키고, 업 무환경을 개선한다면 직무만족도를 향상시킬 수 있음을 의미한다. 이 결과는 Kwon \& Woo (2015)의 호텔 여성직원의 감정노동이 직 무만족에 미치는 영향에서 내면행위는 직무만족에 영향을 주지만 표면행위는 영향을 주지 못한다는 결과와 일치한다.

$\mathrm{H} 2-2$. 감정노동 내면행위는 직무만족에 유의미한 정 $(+)$ 의 영향을 미치는 변인으로 나타났다(표준화 경로계수 0.496 , $p<0.001)$. 이는 피부미용 종사자가 고객 응대 시 진실한 마음으로 감정을 표현 시 직무만족이 높다는 것을 의미한다. 이 결과는 직장 에서 실제로 웃음을 표현하고 "거짓"이라고 느끼지 않는 직원은 자 신의 부정적 감정을 속이고 웃음을 표현한 직원보다 만족도가 높 다는 Adelmann (1995)의 연구결과와 일치한다.

$\mathrm{H} 3-1$. 감정노동 표면행위는 이직의도에 유의미한 정 $(+)$ 의 영향을 미치는 변인으로 나타났다(표준화 경로계수 0.124 , $p<0.05)$. 이는 피부미용 종사자가 고객 응대 시 자신의 감정을 속 이고 긍정적인 것처럼 가장하는 행위가 이직의도를 높인다는 것 을 의미한다. 이 결과는 Cho \& Chang (2015)의 화장품 판매원의 표면행위 수준이 높아질수록 이직의도가 높아졌다는 연구결과와 Shim \& Kim (2013)의 호텔직원의 표면행위 감정노동이 이직의 도에 정(+)의 영향을 미친다는 연구결과와 일치하며, Lee (2017) 의 미용사의 감정노동이 이직의도에 정 $(+)$ 의 영향을 미친다는 연 구결과와도 일치한다.

H3-2. 감정노동 내면행위는 이직의도에 유의미한 부(-)의 영 향을 미치는 변인이라는 가설은 통계적으로 유의하지 않는 것으 로 나타났다. 이는 피부미용 종사자의 내면행위는 이직의도에 직 접적으로 영향을 주지 않는다는 것을 의미한다. 이직의도는 임금, 근무환경 등 다양한 변수가 적용되므로 긍정적 마인드의 내면행위 로 단순히 해석하기에 무리가 있기 때문이라 판단된다. 이 결과는 Lee \& Kim (2011)의 패밀리 레스토랑 종업원의 감정노동을 연구 한 결과와 일치한다.

H4. 직무스트레스는 직무만족에 유의미한 부(-)의 영향을 미치 는 변인으로 나타났다(표준화 경로계수 $-0.235, p<0.001$ ). 이는 피부미용 종사자의 직무스트레스가 높을수록 직무만족이 낮아진 다는 것을 의미한다. 이 결과는 주얼리 산업종사원의 서비스 접점 에서 직무스트레스가 낮을수록 직무만족이 올라간다는 Bae et al. (2015)의 연구결과와 일치한다.

H5. 직무스트레스는 이직의도에 유의미한 정( $(+)$ 의 영향을 미 치는 변인으로 나타났다(표준화 경로계수 $0.318, p<0.001$ ). 이
는 피부미용 종사자의 직무스트레스가 높을수록 이직의도가 높아 진다는 것을 의미한다. 이 결과는 화장품 판매원에 대해 연구한 Cho \& Chang (2015)과 Im (2017), 의료기관 종사자에 대해 연 구한 Chae \& Bae (2014) 및 미용종사자에 대해 연구한 Park et al. (2013) 등의 연구결과, 즉 직무스트레스가 높을수록 이직의도 가 증가한다는 결과와 일치한다.

H6. 직무만족은 이직의도에 유의미한 부(-)의 영향을 미치는 변인으로 나타났다(표준화 경로계수 $-0.253, p<0.001$ ). 이는 피 부미용 종사자의 직무만족이 높을수록 이직의도가 낮아진다는 것 을 의미한다. 이 결과는 Cho \& Chang (2015), Kang \& Rhee (2012), Park et al., (2013)의 연구에서도 동일한 결과가 나타났 다.

\section{Conclusion}

본 연구는 피부미용사의 감정노동(표면행위, 내면행위)이 직무 스트레스, 직무만족, 이직의도에 미치는 영향을 알아봄으로써 효 율적인 인적 관리 방안을 모색하고자 하였다. 연구결과, 피부미 용사의 감정노동 표면행위가 증가할수록 직무스트레스와 이직의 도가 증가하였고, 감정노동 내면행위가 증가할수록 직무스트레스 는 감소하고, 직무만족은 증가하였다. 피부미용사의 직무스트레 스 증가는 직무만족도를 낮추고, 이직의도를 높게 하였으며, 직무 만족도가 높은 경우 이직의도는 감소하였다. 피부미용사의 이직 의도를 감소시키기 위해서는 감정노동의 감소와 직무만족을 향상 시키는 방안이 필요하다. 감정노동을 감소시키기 위해서는 피부 미용사의 자존감 향상 교육, 스트레스 관리법 등의 체계적인 교육 과 불량고객에 대한 적극적인 대응 방안이 필요하다고 판단된다. 직무만족을 향상시키기 위해서는 손님 대응 후 일정시간의 개인 공간 및 시간을 보장함으로써 감정유발 시 스스로 감정조절에 긍 정적인 해석을 할 수 있는 근무환경 개선과 더불어 고객제일주의 고객 응대법에 대한 개선이 필요하다고 판단된다. 본 연구는 연구 대상의 지역적, 대상인원의 한계로 이를 일반화 하기에 무리가 있 으며 후속 연구에서는 더 많은 지역과 인원의 확대가 필요할 것이 다.

\section{References}

Adelmann PK. Emotional labor as a potential source of job stress. In: Organizational risk factors for job stress. Sauter SL, Murphy LR (ed.), American Psychological Association, Washington, DC, pp371-381, 1995.

Bae IY, Nam TW, Jin CH. Study of dissonance, job stress, and 
satisfaction on service work's emotional labor. Regional Industry Review, 38: 51-80, 2015.

Brotheridge CM, Grandey AA. Emotional labor and burnout: comparing two perspectives of "people work". Journal of Vocational Behavior, 60: 17-39, 2002.

Cha YL, Youn CS. A study of cognition on the skin beauty shops's welfare benefits system. Asian Journal of Beauty and Cosmetology, 13: 135-145, 2015.

Chae JA, Bae SW. A study on the effects of medical employee's emotional labor on turnover intention and customer orientation: mediated by job stress and job satisfaction. Journal of Marketing Management Research, 19: 133-152, 2014.

Cho SY, Chang MS. A study on job stress and turnover intention stemming from emotional labor among cosmetic salesmen. Journal of The Korean Society of Cosmetology, 21: 1010-1020, 2015.

Chun HY, Jin YM. Emotional intelligence and emotional labor of hair beauty practitioners impact on job performance. Journal of The Korean Society of Cosmetology, 21: 12031211, 2015.

Fornell C, Larker DF. Evaluating structural equation models with unobservable variables and measurement errors. Journal of Marketing Research, 18: 39-50, 1981.

Goodwin RE, Groth M, Frenkel SJ. Relationships between emotional labor, job performance, and turnover. Journal of Vocational Behavior, 79: 538-548, 2011.

Grandey AA. Emotion regulation in the workplace: a new way to conceptualize emotional labor. Journal of Occupational Health Psychology, 5: 95-110, 2000.

Hochschild AR. Emotion work, feeling rules and social structure. American Journal of Sociology, 85: 551-575, 1979.

Hochschild AR. The managed heart: commercialization of human feeling. University of California Press, Berkeley, pp89-161, 1983.

Im JM. The effect of cosmetic salesperson's emotional labor on job burnout. Journal of the Korean Society of Cosmetology, 20: 870-877, 2014.

Im JM. Effect of women's cosmetics salesperson's emotional labor on job stress. Journal of Investigative Cosmetology, 12: 235-242, 2016.

Im JM. Effect of cosmetics salesperson's emotional labor and job stress on turnover intention. Journal of
Investigative Cosmetology, 13: 287-293, 2017.

Jung SH, Shim SN. Effect of emotional labor and psychosocial stress of hairdressers in beauty shops on customer orientation. Journal of Investigative Cosmetology, 8: 3338, 2012.

Kang JA, Rhee YJ. A study on the relationships among emotional labor, job satisfaction and turnover intention of beauty industry professionals. The Research Journal of the Costume Culture, 20: 664-678, 2012.

Kim JY. The effect of emotional labor on burnout of esthetician. Journal of The Korean Society of Cosmetology, 18: 11411151, 2012.

Kim JY. The effects of job stress on emotional labor of esthetician. Journal of The Korean Society of Cosmetology, 20: 51-61, 2014.

Kim SM, Kim TH, Choi WS. Effect that skin care shop brand image has on customer satisfaction and revisit. Journal of the Korean Society of Beauty and Art, 12: 215-226, 2011.

Kwon KW, Woo SK. A study on effects of female staff's emotional labor at customer contact points on job satisfaction and turnover intention. Journal of Hotel \& Resort, 14: 295-311, 2015.

Lee HY, Kim E, Jung M. Effects of emotional labor and occupational stress on nail salon workers' depression. Journal of the Korean Society of Cosmetology, 22: 1026-1031, 2016.

Lee JT, Kim HC. The structural relationship of emotional labor, job stress, job burnout, and turnover intention: a case of customer contact employees in family restaurant. Journal of Tourism and Leisure Research, 23: 299-317, 2011.

Lee YA. The influences of the emotional labor of the beauty treatment employees on their intentions to change their jobs: centered on the mediating effects of the job satisfaction. Journal of Korea Design Forum, 56: 7-16, 2017.

Lee YJ, Lee JC, Lim JK. The effects of beauty service industry employees' job satisfaction on perception of service quality by customers. Asian Journal of Beauty and Cosmetology, 10: 79-90, 2012.

Oh JH, Song YS. The relations on job satisfaction according to job stress and emotional labor of the hair beauticians. Journal of the Korean Society of Cosmetology, 21: 653- 
663, 2015.

Park EJ, Park OL. The impact of service quality and human service factors on customer satisfaction for different types of beauty shops. Journal of the Korean Society of Beauty and Art, 11: 175-189, 2010.

Park YJ, Han EH, Lim JS, Han CJ. A study on the effects of the beauty industry work's occupational stress, job satisfaction and emotional labor on turnover intention. Asian Journal of Beauty and Cosmetology, 11: 111118, 2013.

Pugliesi K. The consequences of emotional labor: effects on work stress, job satisfaction, and well-being. Motivation and Emotion, 23: 125-154, 1999.

Shim CH, Kim YS. The effects of hotel employees' emotional labor on turnover intention: focused on moderating effects of coping strategy. Journal of Foodservice Management, 16: 265-283, 2013.
Shin HR, Mo JH. The control role of social support in the effects of emotional labor in esthetician on occupational burnout and satisfaction. Journal of the Korean Society of Design Culture, 23: 349-358, 2017.

Sin DY, Chung YJ. Moderating effect of recognition of organization support between emotional labor and job stress of beauty service workers. Journal of Investigative Cosmetology, 13: 133-139, 2017.

Totterdell P, Holman D. Emotion regulation in customer service roles: testing a model of emotional labor. Journal of Occupational Health Psychology, 8: 55-73, 2003.

Yoo SJ, Hwang BG, Lim JS. A study of the relationship between emotion labors and work stress among esthetician. Journal of the Korean Society of Beauty and Art, 13: 61-74, 2012. 


\section{국문초록}

\section{피부미용사의 감정노동이 직무스트레스, 직무만족, 이직의도에 미치는 영향}

서상숙, 박철호

남부대학교 향장미용학과, 광주, 한국

목적: 본 연구는 피부미용사의 감정노동이 직무스트레스, 직무만족, 이직의도에 미치는 영향을 알아봄으로써 효율적인 인적관리방 안을 모색하고자 하였다. 방법: 본 연구의 실증분석을 위해 statistical package for social science (SPSS) 18.0 통계 패키지 프로그 램과 autonomous marine operations and systems (AMOS) 18.0 프로그램을 활용하여 분석하였다. 조사대상자의 일반적 특성을 알 아보기 위하여 빈도분석(frequency analysis)을 실시하였다. 측정도구의 타당성 검증을 위해 탐색적 요인분석을 실시하였고, 요인들 의 신뢰도 검증을 위해 Cronbach's $\alpha$ 계수를 산출하였다. 연구가설을 검증하기 위해 구조방정식 모형을 활용하여 구성 개념들 간 인 과관계를 검증하였다. 결과: 연구결과 피부미용사의 감정노동 표면행위가 증가할수록 직무스트레스와 이직의도가 증가하였고, 감 정노동 내면행위가 증가할수록 직무스트레스는 감소하고, 직무만족은 증가하는 것으로 나타났다. 피부미용사의 직무스트레스 증가 는 직무만족도를 낮추고, 이직의도를 높게 하였으며, 직무만족도가 높은 경우 이직의도는 감소하는 것으로 나타났다. 결론: 피부미 용사의 이직의도를 감소시키기 위해서는 감정노동의 감소와 직무만족을 향상시키는 방안이 필요하다. 감정노동을 감소시키기 위해 서는 피부미용사의 자존감 향상교육, 스트레스 관리법 등의 체계적인 교육과 불량고객에 대한 적극적인 대응방안이 필요하며, 직무 만족을 향상시키기 위해서는 근무환경 개선과 더불어 고객 제일주의 고객 응대법에 대한 개선이 필요하다.

핵심어: 피부미용사, 감정노동, 스트레스, 직무만족, 이직의도

\section{참고문헌}

강주아, 이영주. 미용서비스업 종사자의 감정노동과 직무만족 및 이직의도의 관계분석. 복식문화연구, 20: $664-678$, 2012.

김세미, 김태희, 최우석. 피부관리실 브랜드 이미지가 고객만족 및 재방문에 미치는 영향. 한국인체미용예술학회지, 12 : 215-226, 2011.

김주연. 피부미용사의 감정노동이 소진에 미치는 영향. 한국미용학회지, 18: 1141-1151, 2012.

김주연. 피부미용사의 직무스트레스가 감정노동에 미치는 영향. 한국미용학회지, 20: 51-61, 2014.

권기완, 우성근. 고객접점 여성 직원의 감정노동이 직무만족과 이직의도에 미치는 영향에 관한연구. 호텔리조트연구, 14 :

295-311, 2015.

박은정, 박옥련. 뷰티샵 분류에 따른 서비스품질, 인적서비스 요인이 고객만족에 미치는 영향. 한국인체미용예술학회지, 11: $175-189,2010$.

박유정, 한은희, 임진숙, 한채정. 직무스트레스, 직무만족도, 감정노동이 미용종사자의 이직의도에 미치는 영향연구. 아시 안뷰티화장품학술지, 11: 111-118, 2013.

배인열, 남태웅, 진창현. 서비스 접점의 종사원 감정노동이 감정부조화, 직무스트레스, 직무만족에 미치는 영향에 관한 연 구. 지역산업연구, 38: 51-80, 2015.

신다영, 정연자. 미용 서비스 종사자의 감정노동과 직무스트레스 간 조직지원인식의 조절효과. 대한미용학회지, 13: 133139, 2017.

신향란, 모정희. 피부미용사의 감정노동이 직무소진 및 직무만족에 미치는 영향에 있어 사회적 지원의 조절적 역할에 관한 연구. 한국디자인문화학회지, 23: 349-358, 2017.

심철현, 김윤식. 호텔직원의 감정노동이 이직의도에 미치는 영향: 대처전략의 조절효과를 중심으로. 외식경영연구, 16 : 
265-283, 2013.

오정훈, 송연숙. 헤어 미용업 종사자들의 직무 스트레스와 감정노동에 따른 직무만족과의 관계. 한국미용학회지, 21 : 653-663, 2015.

유수정, 황보각, 임진숙. 피부 미용사의 감정노동과 직무 스트레스와의 관계. 한국인체미용예술학회지, $13: 61-74$, 2012.

이영아. 미용종사원의 감정노동이 이직의도에 미치는 영향: 직무만족의 매개효과를 중심으로. 한국디자인포럼, 56 : 7-16, 2017.

이영주, 이재철, 임재국. 미용서비스산업 종사자들의 직무만족이 고객의 서비스품질 지각에 미치는 영향. 아시안뷰티화장 품학술지, 10: 79-90, 2012.

이정탁, 김현철. 감정노동, 직무스트레스, 직무소진, 이직의도 간의 구조적 관계. 관광레저연구, 23: 299-317, 2011.

이화용, 김은수, 정민수. 네일 살롱 종사자들의 감정노동과 직무스트레스가 우울감에 미치는 영향. 한국미용학회지, 22 : 1026-1031, 2016.

임정미. 화장품 판매원의 감정노동이 직무소진에 미치는 영향. 한국미용학회지, 20: 870-877, 2014.

임정미. 화장품 판매 여성의 감정노동이 직무스트레스에 미치는 영향. 대한미용학회지, 12: 235-242, 2016.

임정미. 화장품 판매원의 감정노동과 직무스트레스가 이직의도에 미치는 영향. 대한미용학회지, 13: 287-293, 2017.

정숙희, 심선녀. 미용실 헤어분야 종사자들의 감정노동과 사회 심리적 스트레스가 고객 지향성에 미치는 영향. 대한미용학 회지, 8: 33-38, 2012.

조소윤, 장미숙. 화장품 판매원의 감정노동에 따른 직무스트레스와 이직의도. 한국미용학회지, 21: 1010-1020, 2015.

차유림, 윤천성. 피부미용실의 복리후생 시스템 인식도 조사 연구. 아시안뷰티화장품학술지, 13: 135-145, 2015.

천혜숙, 진용미. 감성지능과 감정노동이 헤어미용종사자의 직무성과에 미치는 영향. 한국미용학회지, 21: 1203-1211, 2015.

채주아, 배상욱. 의료기관 종사자들의 감정노동이 이직의도, 고객 지향성에 미치는 영향에 관한 연구. 마케팅관리연구, 19: 133-152, 2014. 


\section{中文摘要}

\section{皮肤美容师的情绪劳动对工作压力，满意度和离职率的影响}

徐相淑, 朴哲浩*

南部大学香妆美容学科, 光州，韩国

目的：通过调查皮肤美容师的情绪劳动对工作压力, 工作满意度和离职倾向的影响来寻求有效的人力管理计 划。方法: 为了对本研究进行实证分析, 使用了 statistical package for social science (SPSS) 18.0统计软件包 程序和autonomous marine operations and systems (AMOS) 18.0程序。为调查研究对象的一般特征进行了 频率分析。利用探索性因素分析来验证测量工具的可靠性, 为验证因素的可靠性, 计算Cronbach's $a$ 系数。为 了验证研究假设, 使用结构方程模型验证了结构之间的因果关系。结果: 随着情绪劳动的深层行为的增加, 工 作压力和离职意愿随着情绪劳动的表面行为的增加而增加, 工作压力减少，工作满意度增加。随着工作压力增 加, 工作满意度下降, 离职意愿增加; 离职意愿随着工作满意度增加而下降。结论: 为了减少皮肤美容师的离 职意图, 有必要提高工作满意度和减少情绪劳动。为了减少情绪劳动, 需要对皮肤美容师进行自尊改善培训, 压力管理和针对不良客户的积极相应措施等系统化教育, 有必要改善工作环境和改善客户至上的服务方式来提 高工作满意度。

关键词: 皮肤美容师, 情绪劳动, 压力, 职务满意, 离职意图 
